\title{
MODALITAS KÖNNEN DALAM KALIMAT BAHASA JERMAN
}

\author{
oleh Sulis Triyono \\ FBS Universitas Negeri Yogyakarta
}

\begin{abstract}
This article is an introduction to the basic concept of using the modality of können 'can' in German sentences. The können unit of modality functions to reveal the speaker's attitude and has the status of a verb modifier. Modality is divided in function by some linguists into different areas like epistemic modality, modalitymarking adverb, and deciderative and optative mode devices.

On the basis of the results of a study conducted, it could be concluded that the modality unit of können 'can' in a sentence in German has the characteristics as follows: (1) it is merely an attributive element in a verb phrase rather than a core one so that if deleted the sentence remains grammatical, (2) its relation to any other element is loose in nature, and (3) its position is so firm that it cannot be permutated with any other element in a sentence. In addition, in sentences the können modality varies in meaning according to sentence context. The meaning expressed by the können modality can be of possibility, ability, or permission.
\end{abstract}

Keywords: the können modality

\section{A. PENDAHULUAN}

Pada prinsipnya, bahasa terdiri atas dua lapisan, yaitu lapisan bentuk dan lapisan arti yang dinyatakan oleh bentuk itu (Ramlan, 1986: 25). Bentuk bahasa terdiri atas satuansatuan gramatikal yang berupa wacana, kalimat, klausa, frasa, kata, dan morfem. Bentuk-bentuk itulah yang digunakan oleh para penutur bahasa dalam suatu komunikasi verbal.

Dalam kalimat bahasa Indonesia, kita sering mendengar atau bahkan menggunakan modalitas dapat dan konstruksi lain yang mengandung modalitas itu seperti terdapat, mendapat, dapat saja, dan lain sebagainya. Satuan-satuan itu ada yang menggambarkan sikap pembicara, yang kemudian dikenal dengan modalitas, seperti modalitas dapat dalam kalimat bahasa Indonesia berikut ini.

(1) Dia dapat menyelesaikan tugas itu dalam dua hari.

(2) Saya dapat mengemudikan mobil.
Namun dalam kalimat bahasa Jerman fungsi modalitas dapat dan konstruksikonstruksi lain yang mengandung modalitas memiliki bentuk yang berbeda dibandingkan dengan modalitas dapat dalam kalimat bahasa Indonesia. Kedua kalimat dalam bahasa Indonesia pada data (1) dan (2), apabila dialihbahasakan ke dalam kalimat bahasa Jerman akan memiliki bentuk sebagai berikut.

(3) Er kann seine Aufgabe in zwei Tagen machen.

'Dia dapat menyelesaikan tugas itu dalam dua hari'.

(4) Ich kann das Auto steuern.

'Saya dapat mengemudikan mobil'.

Dalam kalimat bahasa Jerman, modalitas dapat ditandai dengan kata können. Bentuk können dalam kalimat bahasa Jerman akan mengalami berbagai perubahan bentuk bergantung dari slot nominatif dalam kalimat yang mengisi fungsi subjek dalam kalimat 
bahasa Jerman itu. Perubahan modalitas können 'dapat' sebagai akibat adanya pengaruh subjek dalam kalimat bahasa Jerman disebut konjugasi. Variasi bentuk konjugasi modalitas können sebagai berikut.

\begin{tabular}{|l|l|l|}
\hline \multicolumn{1}{|c|}{ Singular } & \multicolumn{1}{c|}{ Konjugasi } & \multicolumn{1}{c|}{ Glos } \\
\hline 1. Person: ich & kann .. & 'saya dapat ..' \\
\hline 2. Person: du & kannst .. & 'kamu dapat ..' \\
\hline 3. Person: er (sie/es) & kann .. & 'dia dapat ..' \\
\hline \multicolumn{1}{|c|}{ Plural } & & \\
\hline 1. Person: wir & können .. & 'kami dapat ..' \\
\hline 2. Person: ihr & $\begin{array}{l}\text { könnt .. } \\
\text { Sie }\end{array}$ & $\begin{array}{l}\text { können.. } \\
\text { kölian dapat ..' }\end{array}$ \\
\hline 3. Person: sie & können .. & 'mereka dapat ..' \\
\hline
\end{tabular}

Kalau kita cermati data (3) dan (4) pada kedua kalimat bahasa Jerman tersebut di atas, bentuk modal können berubah menjadi bentuk kann disebabkan oleh akibat adanya proses konjugasi penyesuaian bentuk kata ganti orang kedua tunggal pada data (3) dan kata ganti orang pertama tunggal pada data (4).

Data nomor (3) Er kann seine Aufgabe in zwei Tagen machen 'Dia dapat menyelesaikan tugas itu dalam dua hari'. Kata er sebagai kata ganti orang kedua tunggal mempengaruhi bentuk modal können menjadi bentuk kann. Sedangkan verba inti machen 'menyelesaikan' yang mengikuti modalitas können, letaknya berubah menjadi di akhir kalimat. Kalimat pada data (3) tersebut sebelumnya adalah Er macht seine Aufgabe in zwei Tagen 'Dia menyelesaikan tugas itu dalam dua hari'.

Demikian pula pada data (4) Ich kann das Auto steuern 'Saya dapat mengemudikan mobil'. Bentuk modal können berubah menjadi bentuk kann sebagai akibat adanya peran ich sebagai kata ganti orang pertama tunggal. Sedangkan kedudukan verba inti steuern 'mengemudikan' yang terikat fungsinya dengan modal können letaknya juga berada dibelakang kalimat bahasa Jerman.

Kedudukan modalitas können 'dapat' dalam kalimat bahasa Jerman seperti tersebut di atas, mempunyai status sebagai pewatas verba, sehingga satuan itu tidak dapat digunakan sebagai verba utama (Alwi, 1992: 96). Modalitas können 'dapat' apabila berfungsi sebagai verba utama, maka dalam kalimat bahasa Jerman tidak diikuti oleh verba lain yang terletak di akhir kalimat. Dalam ragam lain, modalitas können 'dapat' dalam kalimat bahasa Indonesia digunakan sebagai bentuk lain dari mendapat yang menyatakan memperoleh, sehingga dapat digunakan sebagai verba utama. Fungsi modalitas können 'dapat' dalam kalimat bahasa Indonesia tidak selalu berterima dalam kalimat bahasa Jerman. Hal ini disebabkan oleh adanya fitur keluwesan modalitas können 'dapat' dalam bahasa Indonesia yang sangat longgar. Sedangkan modalitas können 'dapat' dalam bahasa Jerman bersifat tak longgar.

Kata dapat yang dimaksudkan dalam uraian di atas, misalnya:

(5) Jangan bicara terlalu keras jika kamu tidak ingin dapat teguran dari guru.

(6) Tadi adik dapat uang dari ibu.

Akan tetapi modalitas können 'dapat' tersebut tidak selalu dapat dialihbahasakan ke dalam bahasa Jerman dengan bentuk kalimat yang sama. Kalimat pada data (5) dalam bahasa Jerman akan menjadi 'Wenn der Lehrer dich nicht schlestes Gelaun hätte, spreche bitte nicht zu laut!' dan kalimat pada data (4) menjadi Die Mutter hat dem jungeren Bruder das Geld gerade abgegeben.

Modalitas können 'dapat' sebagai modalitas seperti halnya modalitas lainnya tidak mempunyai arti tersendiri, tetapi bertugas menunjukkan cara (modus) yang digunakan untuk menyatakan makna pikiran atau untuk mengubah arti suatu ungkapan (Hollander dalam Alwi, 1992: 7)

Pembicaraan mengenai satuan pewatas verba yang menggambarkan sikap pembicara ini memang sudah banyak dilakukan. Akan tetapi umumnya pembicaraan itu menyangkut hal-hal yang umum, seperti oleh Alwi (1992) dan Sudaryanto (1983), sedang pembicaraan yang hanya sepintas dilakukan oleh Kridalaksana (1986) dan Verhaar(1996). 
Tulisan ini mengkaji modalitas können 'dapat' dalam kalimat bahasa Jerman yang berstatus sebagai pewatas verba, yakni yang oleh Sudaryanto (1983) disebut pendesak potensial, oleh Alwi (1992) disebut modalitas epistemik, oleh Kridalaksana (1986) disebut adverbia penanda modalitas, dan oleh Verhaar (1996) dinamakan alat modus desideratif atau optatif, seperti pada contoh data (1) dan (2). Dengan demikian, satuan dapat yang berstatus di luar contoh data nomor (3) dan (4) untuk sementara dikesampingkan.

Permasalahan dalam tulisan ini adalah penggunaan modalitas können 'dapat' dalam kalimat bahasa Jerman sebagai pewatas verba. Permasalahan tersebut dapat dirumuskan sebagai berikut.

1. Bagaimana ciri-ciri sintaksis modalitas können 'dapat' dalam bahasa Jerman?

2. Apa makna modalitas können 'dapat'dalam kalimat bahasa Jerman?

Secara garis besar tulisan ini bertujuan untuk mengamati modalitas können 'dapat' dalam kalimat bahasa Jerman. Berdasarkan ancangan di atas, tulisan ini diharapkan dapat mengungkap hal-hal sebagai berikut: (1) ciri sintaksis modalitas können 'dapat' dalam kalimat bahasa Jerman, dan (2) makna modalitas können 'dapat' dalam kalimat bahasa Jerman.

\section{B. FUNGSI MODALITAS KÖNNEN}

Pendapat para ahli yang satu dengan ahli yang lain mengenai modalitas sampai saat ini masih sering berbeda-beda. Akan tetapi, mereka umumnya sepakat bahwa modalitas merupakan gambaran sikap pembicara dan statusnya sebagai pewatas verba. Bentuk yang menggambarkan sikap pembicara itu, ada yang berapa unsur gramatikal dan ada pula yang berupa unsur leksikal.

Dalam bahasa Indonesia, pengungkapan sikap pembicara itu lazim diwujudkan dengan unsur leksikal. Meskipun tidak menutup kemungkinan muncul pula dalam unsur gramatikal, seperti pemakaian di dalam kalimat bahasa Indonesia diminum (esnya)!
Dimakan (kuenya)! Unsur leksikal yang biasa digunakan untuk mengungkapkan modalitas, antara lain dapat, boleh, bisa, mau, mampu, akan, harus, dan sudah. Hal inilah yang dikategorikan sebagai kelonggaran unsur leksikal modalitas können 'dapat' dalam kalimat bahasa Indonesia. Sedangkan dalam bahasa Jerman bersifat tidak longgar karena fungsi modalitas können 'dapat' hanya memiliki dua makna, yaitu sebagai subjektiv dan objektiv. Makna subjektiv modalitas können 'dapat' yaitu kemungkinan, kemampuan, dan izin. Makna objektiv yaitu 'dapat' dan bukan berarti bersifat longgar menjadi bentuk leksikal *mendapat atau dalam bahasa Jerman disebut 'bekommen'. Modalitas können 'dapat' menurut Engel (1991: 477) dan Buscha (1992: 32) tidak berdiri sebagai verba inti, melainkan sebagai verba bantu yang menjelaskan verba intinya dalam kalimat bahasa Jerman.

Secara jelas, Kridalaksana (1984: 125) memberi batasan modalitas sebagai cara pembicara menyatakan sikap terhadap suatu situasi dalam suatu komunikasi antar pribadi atau makna kemungkinan, keharusan, kenyataan dan sebagainya yang dinyatakan dalam kalimat. Dalam bahasa Indonesia keluwesan modalitas können 'dapat' dinyatakan dengan kata-kata seperti barangkali, harus, akan, dan sebagainya atau dengan adverbia kalimat seperti pada hakekatnya, menurut hemat saya, dan sebagainya.

Senada dengan hal itu, Alwi (1992: 5) setuju bahwa modalitas lebih banyak berhubungan dengan sikap pembicara terhadap apa yang dikemukakan dalam tuturannya. Meskipun demikian, sikap pembicara itu masih memerlukan penelasan lebih lanjut. Dalam penjelasannya Alwi (Ibid, 36-252) membedakan modalitas menjadi 4 (empat) macam, yaitu modalitas intensional (keingingan, harapan, ajakan, permintaan), modalitas epistemik (kemungkinan, keteramalan, keharusan, kepastian), modalitas deontik (izin, perintah) dan modalitas dinamik (kemampuan).

Dengan menggunakan istilah pendesak yang dirumuskan sebagai pewatas verba yang 
mengisi fungsi predikat, Sudaryanto (1983: 177) mengungkapkan bahwa apa yang disebut modalitas itu identik dengan pendesak, yang berupa pendesak interogatif (apa, apakah, -kah, $\mathrm{dsb}$ ), pendesak potensial (dapat, bisa, mampu), pendesak desideratif (mau, hendak, perlu, harus), pendesak habitual (suka, senang, biasa, takut, mudah, sulit), dan pendesak dubitatif (mungkin, barangkali).

Berdasarkan pada uraian tersebut di atas, terlihat bahwa satuan modalitas können 'dapat' sejajar dengan satuan bisa, mampu dan boleh sebagai pendesak potensial. Pendesak potensial merupakan pendesak sekunder, dalam arti bahwa identitasnya sebagai pendesak ditentukan oleh ada tidaknya kesamaan watak dengan negatif dan interogatif dalam hal ketentuan letaknya (Sudaryanto, 1983: 73). Pendesak di sini mempunyai status sebagai pembatas verba dan dalam bahasa Indonesia cenderung dihipotesiskan terdapat mengawali verba dalam struktur P O. Sedangkan dalam bahasa Jerman sering disebut adanya unsur inti yang bersifat objektiv dan bersifat subjektiv ditinjau dari sikap pembicara.

\section{MODALITAS KÖNNEN DALAM KALIMAT BAHASA JERMAN}

Seperti telah diuraikan di atas, modalitas können 'dapat' dalam bahasa Jerman dan bahasa Indonesia memiliki fungsi yang sama yaitu untuk mengungkapkan sikap pembicara dan mempunyai status sebagai pewatas verba. Satuan modalitas können 'dapat' itu oleh beberapa linguis digolongkan dalam wadah yang berbeda-beda, seperti modalitas epistemik pendesak potensial dan adveria penanda modalitas.

Dalam bahasa Jerman, bentuk modalitas können 'dapat' muncul sebagai pewatas verba seperti dalam bahasa Indonesia. Modalitas ini sering disejajarkan dengan modalitas bisa, boleh, dan mampu. Modalitas können 'dapat' tidak berdiri sebagai verba inti, melainkan sebagai verba bantu yang menjelaskan verba intinya dalam kalimat bahasa Jerman. Berikut disajikan datanya:
(1) Ursula kann charmant plaudern 'Ursula bisa bercakap-cakap dengan amat menarik'.

(2) Der Turm könnte einstürzen 'Menara itu bisa melindunginya'.

(3) So kann man das nicht machen 'orang itu tidak bisa membuatnya'.

Modalitas können 'dapat' pada kalimat Ursula kann charmant plaudern akan menjelaskan bahwa Ursula dapat menjadi charmant. Letak kann dalam kalimat berada pada posisi kedua, sedangkan plaudern berada di akhir suatu kalimat. Untuk mempermudah penjelasan di atas berikut digambarkan posisi modalitas können 'dapat' pada kalimat bahasa Jerman sebagai berikut.

$\frac{\text { Ursula }}{1} \frac{\text { kann }}{2} \frac{\text { charmant }}{3} \frac{\text { plaudern }}{\mathrm{E}}$

Pada posisi nomor 1 ditempati Ursula yang berfungsi sebagai Subjek (S) dalam kalimat. Posisi kedua kann berfungsi sebagai modalitas (M). Posisi ketiga diduduki charmant. Posisi ketiga ini sifatnya sangat longgar, dapat ditempati oleh Ergäzung (E) 'keterangan' atau oleh objek Dativ (D) dan/atau Akkusativ (A) dan bahkan oleh S. Akan tetapi tidak mungkin ditempat oleh M. Posisi terakhir dalam kalimat bahasa Jerman di atas selalu ditempati oleh verba inti. Oleh karena itu, kalimat Ursula kann charmant plaudern dapat menjadi Charmant kann Ursula plaudern tanpa mempengaruhi makna dalam kalimat. Untuk memudahkan pengertian ini, disajikan struktur gramatikal kalimatnya sebagai berikut.

$\frac{\text { Ursula }}{1} \frac{\text { kann }}{2} \frac{\text { charmant }}{3} \frac{\text { plaudern }}{\mathrm{E}}$

Charmant kann Ursula plaudern

\begin{tabular}{cccc}
1 & 2 & 3 & $E$ \\
$*$ Plaudern & $\frac{\text { kann }}{2}$ & $\frac{\text { Ursula }}{3}$ & $\frac{c}{\text { charmant }}$ \\
\hline 1 & 2 & & E
\end{tabular}

$\frac{\text { *Ursula }}{1} \quad \frac{\text { kann }}{2} \quad \frac{\text { plaudern }}{3} \quad \frac{\text { charmant }}{\mathrm{E}}$

Kalimat bertanda * (bintang) tersebut di atas, tidak berterima karena tidak gramatikal dan tidak bermakna. 
Der Turm könnte einstürzen 'Menara itu bisa melindunginya', tidak dapat dibalik seperti pada kalimat Ursula kann charmant plaudern yang menjadi Charmant kann Ursula plaudern. Hal ini disebabkan oleh tidak adanya unsur $E$ atau $D$ atau A dalam kalimat.

Sedangkan pada kalimat pada data (3) So kann man das nicht machen 'orang itu tidak bisa membuatnya' dapat menjadi Man kann so das nicht machen seperti tersebut di atas, tanda mempengaruhi makna dalam kalimat. Dengan demikian, konstruksi kalimat yang mengandung modalitas können 'dapat' dalam bahasa Jerman selalu tetap dan tidak dapat digantikan posisinya oleh kata lain. Jadi, kesimpulannya adalah posisi modalitas können 'dapat' pada kalimat bahasa Jerman selalu berada pada slot kedua dan verba inti selalu berada pada akhir suatu kalimat.

\section{Kadar Keintian Modalitas Können dalam Kalimat Bahasa Jerman}

Sebagai pewatas verba, kehadiran modalitas können 'dapat' merupakan atribut dari verba dalam konstruksi frase verbal. Sedangkan yang dimaksud frase verbal adalah frase yang mempunyai distribusi yang sama dengan kata golongan verba (Ramlan, 1986: 159). Persamaan distribusi itu bisa diketahui dengan jelas dari data berikut ini.

(4) Die Großmutter kann den Brief nicht lesen, sie sieht ohne Brille schlecht.

'Nenek itu tidak dapat membaca surat karena tidak memakai kacamata'.

(5) Die Kinder können ihre Hausaufgabe gut machen.

'Anak-anak itu dapat mengerjakan pekerjaan rumah dengan baik'.

(6) Ich kann mir das Leben im 21. Jahrhundert nicht vorstellen, dazu fehlt mir die nötige Phantasie.

'Saya tidak dapat membayangkan bisa hidup pada abad ke-21, walau masih ada kekurangannya'.

Kalimat (4), (5), dan (6) di atas, mengandung frase verbal dapat membaca, dapat mengerjakan, dan dapat membayangkan yang distribusinya sama dengan verba membaca, mengerjakan dan membayangkan. Dengan demikian, modalitas dapat dalam kalimat tersebut sebagai atribut. Atribut pada kalimat (4), (5), dan (6) bisa dilesapkan menjadi kalimat (4a), (5a), dan (6a). Akan tetapi, setelah dikaji ulang mempengaruhi keutuhan makna dalam kalimat dan hubungan semantis gramatikal antarbagiannya menjadi berubah. Atribut yang dilesapkan pada kalimat (4), (5), dan (6) tersebut menjadi kalimat dengan makna baru sebagai berikut.

(4a) Die Großmutter liest den Brief nicht, sie sieht ohne Brille schlecht.

(5a) Die Kinder machen ihre Hausaufgabe gut.

(6a) Ich stelle mir das Leben im 21. Jahrhundert nicht vor, dazu fehlt mir die nötige Phantasie.

Suatu bukti bahwa kalimat dengan menggunakan modalitas können 'dapat' sebagai atribut dari verba dalam konstruksi frase verbal memiliki tingkat tinggi atau rendah kadar keintian modalitasnya digunakanlah teknik lesap. Apabila kalimat yang salah satu unsurnya dilesapkan tetap gramtikal berarti kadar keintian unsur itu rendah. Begitu pula sebaliknya, apabila salah satu unsur dalam kalimat tersebut tidak dapat dilesapkan berarti kadar keintian unsur itu tinggi. Hal itu tentunya perlu mendapat perhatian bahwa dari proses pelesapan itu, memunculkan suatu kalimat yang tidak mengambarkan secara jelas tentang sikap pembicara atau tidak. Apabila unsur dalam kalimat yang dilesapkan tersebut tetap memiliki makna yang sesuai dengan sikap pembicara, maka kadar keintiannya rendah. Dan sebaliknya, apabila tidak sesuai dengan makna sikap pembicara, maka kadar keintian modalitas können 'dapat' dalam kalimat tinggi. Berdasarkan teknik lesap pada kalimat (4a), (5a), dan (6a) tersebut dapat disimpulkan bahwa ketiga kalimat itu tetap gramatikal dan hubungan antar unsur-unsurnya tidak berubah. Akan tetapi, makna yang terkadung di dalamnya tidak sesuai dengan sikap pembicara. Dengan demikian, kadar keintian modalitas können 'dapat' dalam kalimat bahasa Jerman tinggi. 


\section{Hubungan antara Modalitas Können dan Bagian Lain dalam Kalimat}

Bentuk bahasa yang digunakan oleh masyarakat penuturnya terdiri atas satuansatuan yang sering disebut satuan gramatik. Satuan-satuan itu meliputi wacana, kalimat, klausa, frase, kata, dan morfem (Ramlan, 1986: 25). Dalam suatu tuturan, satuan-satuan itu akan selalu terdiri atas satuan-satuan yang lain sesuai dengan tingkat keluasan satuan itu. Satuan gramatikal kalimat misalnya, terbentuk atas satuan lain yang lebih kecil seperti klausa, frase, kata, dan satuan lainnya. Hubungan antarsatuan gramatik itu ada yang erat, tetapi ada pula yang longgar. Hubungan yang erat artinya antarsatuan itu tidak dapat disisipi satuan lain, sebaliknya hubungan yang longgar mengindikasikan bahwa antara satuan gramtik yang diwatasi dengan satuan yang mewatasi bisa disisipi oleh satuan gramatik lain.

Hubungan antara modalitas können 'dapat' dengan satuan gramatik lain dalam suatu kalimat ternyata bersifat longgar karena antara modalitas können 'dapat' dengan satuan lain itu bisa disisipi satuan lain. Data yang bisa diamati:

(7) Die Schüler können ihre Haufaufgabe machen.

'Murid-murid dapat mengerjakan pekerjaan rumah'.

(8) Die Schüler können ihre Haufaufgabe in einer Stunde machen.

'Murid-murid dapat mengerjakan pekerjaan rumah dalam waktu satu jam'.

(9) Die Schüler können ihre Haufaufgabe in einer Stunde fertig machen.

'Murid-murid dapat mengerjakan pekerjaan rumah dalam waktu satu jam selesai'.

Hubungan modalitas können 'dapat' dengan satuan lain pada kalimat (7), (8), dan (9) tersebut bersifat longgar ditinjau dari unsur gramatikalnya. Hal ini bisa dibuktikan dengan menggunakan teknik sisip. Kalimat (8) merupakan hasil dari teknik sisip pada kalimat (7) yang telah disisipi dengan satuan gramatikal in einer Stunde 'dalam waktu satu jam'. Pada kalimat (8), penyisipan dilakukan setelah satuan modalitas können dengan satuan lain. Sedang pada kalimat (9) telah disisipi dengan satuan gramatikal in einer Stunde fertig 'dalam waktu satu jam selesai'. Penyisipan dilakukan setelah satuan modalitas können dengan satuan lain. Secara gramatikal letak modalitas können selalu berada di slot kedua atau sebagai pengisi predikat dan verba inti di akhir kalimat. Dengan demikian, dapat disimpulkan bahwa secara gramatikal hubungan modalitas können dengan satuan unsur lainnya bersifat longgar.

\section{Ketegaran Letak Modalitas Können dalam Kalimat Bahasa Jerman}

Salah satu sifat kata adalah mempunyai mobilitias luar. Di dalam suatu satuan gramatik yang lebih luas, kata mempunyai kebebasan untuk berpindah tempat. Meskipun demikian, kebebasan itu juga bergantung pada valensi sintaksis dalam satuan itu, sehingga ada kata yang letak ketegarannya rendah dan kata yang letak ketegarannya kuat.

Modalitas können yang merupakan pewatas verba mempunyai ketegaran letak yang cukup kuat (Sudaryanto, 1983: 186). Hal ini bisa dilihat dari ketidakkemungkinan satuan modalitas können ditempatkan selain di posisi kedua atau berada pada fungsi predikat. Sedangkan letak verba inti berada di akhir suatu kalimat. Dengan demikian, modalitas können mengisi fungsi predikat dalam kalimat bahasa Jerman sebagai berikut.

(10) Der Fünfjährige kann bereits lesen, seine Mutter hat es ihm beigebracht.

'Anak berusia 5 tahun mulai bisa membaca, ibu yang mengajarinya'.

(11) *Der Fünfjährige bereits kann lesen, seine Mutter hat es ihm beigebracht.

*Der Fünfjährige bereits lesen kann, seine Mutter hat es ihm beigebracht.

Kalimat (11) dan (12) setelah dilakukan teknik permutasi menjadi tidak gramatikal (bertanda *). Teknik permutasi modalitas pada kalimat bahasa Jerman tersebut digunakan untuk menguji tingkat ketegaran letak modalitas können dalam suatu kalimat. Di dalam pengujian ketegaran letak modalitas 
können dengan menggunakan teknik permutasi dihipotesiskan bahwa apabila modalitas können dapat dipindah-pindah letaknya dalam suatu kalimat, maka tingkat ketegaran letak modalitas können rendah. Dan sebaliknya, apabila tidak bisa dipindah-pindah, maka tingkat ketegaran letak modalitas menjadi kuat.

Berdasarkan pengujian dengan teknik permutasi pada kalimat (11) dan (12) dinyatakan bahwa kedua kalimat tersebut tidak berterima secara gramatikal. Dengan demikian, dapat disimpulkan bahwa ketegaran letak modalitas können dalam kalimat bahasa Jerman bersifat kuat. Ketegaran itu bersifat mutlak karena letak modalitas bahasa Jerman tidak dapat dipindah-pindahkan, tidak seperti kalimat dalam bahasa Indonesia yang dapat dipindahpindah tanpa mempengaruhi makna, misalnya:

(13) Pemeriksaan Imam Samudra dapat saja dipercepat dari jadwal semula.

(13a) Dapat saja pemeriksaan Imam Samudra dipercepat dari jadwal semula.

(13b) Pemeriksaan Imam Samudra dipercepat dari jadwal semula dapat saja.

Berdasarkan data (13) dalam bahasa Indonesia, kalimat yang mengandung modalitas können yang sudah disisipi satuan lain seperti saja, menjadi bentuk dapat+saja dimungkinkan berada di depan subjek. Hal ini bisa dibuktikan dengan menggunakan teknik permutasi, sehingga menjadi kalimat (13a) dan (13b) tetap gramatikal dan berterima.

\section{Makna Modalitas Können dalam Kalimat Bahasa Jerman}

Sebagai alat komunikasi verbal, bahasa merupakan suatu sistem lambang bunyi yang bersifat arbitrer (Cheer, 1990: 1). Demikian pula hubungan antara kata dengan maknanya juga bersifat arbitrer. Artinya tidak ada hubungan wajib antara deretan fonem pembentuk kata itu dengan maknanya. Akan tetapi, hubungan itu bersifat konvensional, artinya disepakati setiap anggota masyarakat suatu bahasa untuk memaknai hubungan itu.

Sebagai bentuk alat komunikasi verbal, modalitas dapat juga mempunyai makna.
Makna modalitas können yang mengungkapkan sikap pembicara, erat katiannya dengan makna epistemik dan makna muasal, yaitu kemungkinan, kemampuan, dan izin. Makna epistemik dan makna muasal dalam kalimat bahasa Jerman diwujudkan dalam bentuk sebagai berikut.

\section{a. Makna Kemungkinan}

Modalitas können dalam suatu kalimat bahasa Jerman bisa memunculkan Möglichkeitsbedeutung 'makna kemungkinan'. Data yang dapat ditunjukan adalah:

(14) Sie kann auch daran gedacht haben

'Dia mungkin juga sudah memikirkannya'

(14a) *Sie hat auch daran gedacht können '*Dia dapat juga sudah memikirkannya'

(14b) *Sie darf auch daran gedacht haben '*Dia boleh juga sudah memikirkannya'

(14c) *Sie ist auch in der Lage, daran gedacht zuhaben

'*Dia mampu juga sudah memikirkannya'

Berdasarkan paparan data (14) di atas dapat kita cermati bahwa untuk opsi verba infinitif *können 'dapat', *darf 'boleh', dan *in der Lage sein 'mampu' tidak dapat dipasangkan, karena dalam konteks kalimat bahasa Jerman tersebut di atas hanya memiliki satu opsi können yang berarti mungkin. Pada data (14a) dalam bentuk kalimat Perfekt posisi kedua dalam kalimat itu diisi oleh verba bantu hat. Padahal, seharusnya diisi oleh modalitas können 'dapat'. Sedangkan verba bantu haben berada pada akhir kalimat, sehingga kalimat (14a) secara gramatikal tidak berterima. Pada data (14b) dan (14c) secara gramatikal dapat dibenarkan, tetapi secara semantik terdapat kesalahan, karena penggunaan modalitas können memiliki makna kemungkinan. Sedangkan penggunaan leksikon yang langsung mengacu pada makna *dapat, *boleh, dan *mampu seperti pada data (14b) dan (14c) menjadi tidak sesuai dengan konteks kalimat. Dengan demikian, makna kalimat Sie kann auch daran gedacht haben berarti 'Dia mungkin 
juga sudah memikirkannya.' Demikian pula terjadi pada kalimat yang terdapat pada data sebagai berikut.

(15) Er kann nicht gekommen sein 'Dia mungkin tidak bisa datang'

(15a) *Er ist nicht gekommen können 'Dia tidak dapat datang'

(15b) *Er darft nicht gekommen sein 'Dia boleh tidak datang'

(15c) *Er ist in der Lage zu kommen 'Dia mampu datang'

Akan tetapi, kalimat Er kann nicht gekommen sein mimiliki dua kemungkinan. Kemungkinan pertama adalah es ist unmöglich, dass er gekommen ist 'dia tidak mungkin bisa datang' dan kemungkinan kedua es ist möglich, dass er nicht gekommen ist 'dia mungkin tidak bisa datang'. Oleh karena itu, opsi yang dipilih dapat berupa dua kemungkinan itu.

Er kann nicht gekommen sein dalam bahasa Jerman dipengaruhi oleh peran modalitas können dalam konteks yang dimaksud oleh pembicara dan sikap pembicara. Oleh karena itu, disebut sebagai makna subjektiv pembicara. Hal ini dapat dijelaskan bahwa argumen pertama Er kann nicht gekommen sein yang berarti 'dia tidak mungkin bisa datang' disebut sebagai Negation des Modalverben 'makna negativ modalitas'. Sedangkan untuk argumen kedua Er kann nicht gekommen sein yang berarti 'dia mungkin tidak bisa datang' disebut sebagai Negation des Hauptverbs 'makna negativ verba inti'.

(16) Ich kann nur schreiben, wenn du mir Papier gibst. 'Saya mungkin hanya bisa menulis saja, apabila kamu memberiku kertas'.

(16a) *Ich schreibe nur, wenn du mir Papier gibst.

(16b) *Ich darf nur schreiben, wenn du mir Papier gibst.

(16c) *Ich bin in der Lage, nur zu schreiben, wenn du mir Papier gibst.

Seperti pada data (14) dan (15) tersebut di atas, bahwa keberterimaan secara gramatikal berpengaruh terhadap keberterimaan secara semantik. Makna semantik tidak terlepas dari konteks dalam kalimat dan bentuk gramatikalnya. Modalitas können 'dapat' pada kalimat di atas, ternyata hanya dapat diganti dengan satuan mungkin yang menggambarkan makna 'kemungkinan', sehingga bisa diidentifikasi bahwa modalitas können di atas mempunyai makna 'kemungkinan'.

\section{b. Makna Kemampuan}

Modalitas können 'dapat' juga mempunyai Fähigkeitsbedeutung 'makna kemampuan'. Data yang bisa diamati:

(17) Man kann dort schon schwimmen, das Wasser ist warm genug.

'Orang itu sudah bisa (mampu) berenang karena airnya cukup hangat'.

(18) Martin kann jetzt schon schwimmen, seine Tante hat es ihm beigebracht.

'Martin sekarang sudah bisa (mampu) berenang, tantenya yang mengajarinya'.

(19) Sie konnte nicht sehen, weil es zu dunkle war.

'Dia tidak mampu melihat karena terlalu gelap'.

Pada ketiga kalimat bahasa Jerman tersebut, makna können memiliki arti kemampuan. Hal ini dapat diuji dari kalimat Man kann dort schon schwimmen 'orang itu bisa berenang'. Makna kann schwimmen 'bisa berenang' pada kalimat tersebut berarti mampu berenang. Demikian pula pada kalimat (18) dan (19) memiliki makna mampu. Modalitas können pada kalimat (18) dan (19) hanya bisa diganti dengan satuan mampu yang menyatakan makna 'kemampuan', sehingga bisa diidentifikasi bahwa satuan modalitas können itu mempunyai makna 'kemampuan'.

\section{c. Makna Izin}

Selain mempunyai makna kemungkinan (Möglichkeitsbedeutung) dan makna kemampuan (Fähigkeitsbedeutung), modalitas können dalam bahasa Jerman memiliki Erlaubnisbedeutung 'makna izin'. Data dapat diamati pada paparan di bawah ini. 
(20) Meinetwegen kann er machen, was er will.

'Tak apalah, dia boleh mengerjakan, sesuai keinginannya'.

(21) Wer mit dem Sprachtest fertig ist, kann nach Hause gehen.

'Siapa yang telah selesai mengerjakan ujian, boleh pulang'.

Untuk memudahkan kita mencermati gejala kebahasaan yang mengandung makna izin adalah data pada kalimat (21) sebagai berikut.

(21) Wer mit dem Sprachtest fertig ist, kann nach Hause gehen. ' Siapa yang telah selesai mengerjakan ujian, boleh pulang'.

(21a) *Wer mit dem Sprachtest fertig ist, darf nach Hause gehen.

(21b) *Wer mit dem Sprachtest fertig ist, ist nach Hause gegangen.

(21c) *Wer mit dem Sprachtest fertig ist, $\underline{\text { ist }}$ nach Hause.

Data (21) menunjukan bahwa penggunaan modalitas können pada kalimat bahasa Jerman hanya bisa diganti dengan modalitas können dalam bahasa Indonesia artinya 'boleh' yang menyatakan makna 'izin'. Dengan demikian, dapat disimpulkan bahwa modalitas können dalam kalimat bahasa Jerman mempunyai makna 'izin'. Untuk mengungkap makna izin dalam kalimat bahasa Jerman tersebut menggunakan makna subjektiv modalitas können karena ditinjau dari sikap pembicara. Dengan demikian, data (21a), (21b), dan (21c) secara semantik tidak berterima.

\section{PENUTUP}

\section{Simpulan}

Modalitas dalam bahasa Jerman mempunyai fungsi dan makna sesuai dengan konteksnya masing-masing. Modalitas atau pendesak potensial dalam bahasa Jerman menggambarkan sikap pembicara terhadap hal yang dibicarakan. Pengungkapan itu bisa dengan unsur gramatikal dan bisa pula dengan unsur leksikal. Kajian modalitas ini termasuk kajian pada modalitas epistemik atau pendesak potensial.

Berdasarkan perilaku sintaksisnya modalitas können dalam kalimat bahasa Jerman mempunyai ciri-ciri: (1) bukan sebagai unsur inti, hanya sebagai atribut dalam frase verba, sehingga jika dilesapkan kalimatnya tetap gramatikal, (2) hubungan unsur modalitas können dengan unsur-unsur lain bersifat longgar, (3) ketegaran letak modalitas können sangat kuat dan bersifat mutlak sehingga tidak bisa dipermutasikan dengan unsur lain dalam suatu kalimat.

Selain itu, modalitas können dalam kalimat bahasa Jerman mempunyai makna yang berbeda-beda bergantung pada konteks kalimatnya. Makna yang dinyatakan oleh modalitas können berupa makna 'kemungkinan', 'kemampuan', dan 'izin'.

\section{Implikasi}

Berdasarkan pengkajan tersebut di atas, dapat dikemukakan implikasinya dalam pengajaran bahasa Jerman sebagai berikut. Modalitas können dalam kalimat bahasa Jerman berfungsi untuk menyatakan sikap pembicara. Dalam merealisasikan sikap pembicara untuk mengungkapkan makna kemungkinan, makna mampu, dan makna izin dapat digunakan modalitas können. Kadar keintian modalitas können tersebut sangat tinggi. Sebagai pewatas verba, kehadiran modalitas können 'dapat' merupakan atribut dari verba dalam konstruksi frase verbal. Secara gramatikal hubungan antara modalitas können dan unsur lainnya dalam kalimat bahasa Jerman bersifat longgar. Modalitas können memiliki ketegaran yang bersifat mutlak karena letak modalitas können dalam kalimat bahasa Jerman tidak dapat dipindah-pindahkan. Letak modalitas können dalam kalimat pada posisi kedua dan pasangan verba inti yang terkait dengan modalitas berada pada akhir kalimat, seperti berikut: Die Kinder können ihre Hausaufgabe gut machen. Posisi pertama diduduki die Kinder 'anak-anak'. Pada posisi kedua diisi oleh modalitas können 'dapat'. Posisi ketiga diisi oleh ihre Hausaufgabe 'pekerjaan rumahnya'. Posisi keempat diisi 
Ergänzung (E) gut 'baik'. Posisi terakhir dalam kalimat itu diisi oleh verba inti machen 'mengerjakan'. Dengan demikian, kalimat Die Kinder können ihre Hausaufgabe gut machen berarti 'anak-anak itu dapat mengerjakan pekerjaan rumahnya dengan baik'.

\section{DAFTAR PUSTAKA}

Alwi, Hasan. 1992. Modalitas dalam Bahasa Indonesia. Yogyakarta: Kanisius. et. al. 1993. Tata Bahasa Baku Bahasa Indonesia. Jakarta: Departemen Pendidikan dan Kebudayaan.

Buscha, Joachim \& Irene Zoch. 1992. Der Infinitiv. Zur Theorie und Praxis des Deutschunterrichts für Ausländer. Leipzig: Langenscheidt Verlag Enzyklopädie.

Chaer, Abdul. 1990. Pengantar Semantik Bahasa Indonesia. Jakarta: Rineha Cipta.

Engel, Ulrich. 1991. Deutsche Grammatik. Heidelberg: Julius Groos Verlag.
Grebe, Paul. 1973. Duden. Die Grammatik. Mannheim: Duden Verlag.

Kridalaksana, Harimurti. 1984. Kamus Linguistik. Jakarta: Gramedia. 1986. Kelas Kata dalam Bahasa Indonesia. Jakarta: Gramedia.

Ramlan, M. 1986. Ilmu Bahasa Indonesia, Sintaksis. Yogyakarta: Karyono.

Sudaryanto. 1983. Predikat-Objek dalam Bahasa Indonesia, Keselarasan Pola Umum. Jakarta: Djambatan. 1984. Metode Linguistik Bagian Pertama, ke Arah Memahami Metode Linguistik. Yogyakarta: Gadjah Mada University Press. 1986. Metode Linguistik Bagian Kedua, Metode dan Aneka Teknik Pengumpulan Data. Yogyakarta: Gadjah Mada University Press.

Verhaar, J.W.M. 1986. Asas-asas Linguistik Umum. Yogyakarta: Gadjah Mada University Press. 